\title{
Systemic instruction of cell-mediated immunity by the
}

\section{intestinal microbiome [version 1; peer review: 2 approved]}

\author{
John Grainger (iD1,2, Rufus Daw11,2, Kelly Wemyss (iD1,2
}

\begin{abstract}
${ }^{1}$ Lydia Becker Institute of Immunology and Inflammation, Division of Infection, Immunity and Respiratory Medicine, Faculty of Biology, Medicine and Health, The University of Manchester, Manchester Academic Health Science Centre, Manchester, UK ${ }^{2}$ Manchester Collaborative Centre for Inflammation Research, Division of Infection, Immunity and Respiratory Medicine, School of Biological Sciences, Faculty of Biology, Medicine and Health, The University of Manchester, Manchester Academic Health Science Centre, Manchester, UK
\end{abstract}

V1 First published: 07 Dec 2018, 7(F1000 Faculty Rev):1910 https://doi.org/10.12688/f1000research.14633.1

Latest published: 07 Dec 2018, 7(F1000 Faculty Rev):1910

https://doi.org/10.12688/f1000research.14633.1

\section{Open Peer Review}

Approval Status

1

2

version 1

07 Dec 2018

Faculty Reviews are review articles written by the prestigious Members of Faculty Opinions. The articles are commissioned and peer reviewed before publication to ensure that the final, published version is comprehensive and accessible. The reviewers who approved the final version are listed with their names and affiliations.

1. Luis Vitetta, University of Sydney, Sydney, Australia

2. Jonathan Braun, University of California, LoS Angeles, Los Angeles, USA

Any comments on the article can be found at the end of the article. 
Corresponding author: John Grainger (john.grainger-2@manchester.ac.uk)

Author roles: Grainger J: Writing - Original Draft Preparation, Writing - Review \& Editing; Daw R: Writing - Original Draft Preparation; Wemyss K: Writing - Original Draft Preparation

Competing interests: No competing interests were disclosed.

Grant information: John R. Grainger is the recipient of a Senior Fellowship funded by the Kennedy Trust for Rheumatology Research. Rufus H. Daw is supported by the Medical Research Council (MRC) Doctoral Training Programme at The University of Manchester. Kelly Wemyss is supported by the Engineering and Physical Sciences Research Council and MRC Centre for Doctoral Training in Regenerative Medicine at The University of Manchester (EP/L014904/1). This work was also supported in part by The Wellcome Trust (grant 104195/Z/14/Z).

The funders had no role in study design, data collection and analysis, decision to publish, or preparation of the manuscript.

Copyright: ( $) 2018$ Grainger J et al. This is an open access article distributed under the terms of the Creative Commons Attribution License, which permits unrestricted use, distribution, and reproduction in any medium, provided the original work is properly cited.

How to cite this article: Grainger J, Daw R and Wemyss K. Systemic instruction of cell-mediated immunity by the intestinal microbiome [version 1; peer review: 2 approved] F1000Research 2018, 7(F1000 Faculty Rev):1910

https://doi.org/10.12688/f1000research.14633.1

First published: 07 Dec 2018, 7(F1000 Faculty Rev):1910 https://doi.org/10.12688/f1000research.14633.1 


\section{Introduction}

The human intestine houses a tremendous quantity and remarkable diversity of microbes, including bacteria, fungi, viruses, and protozoa. Such organisms, collectively termed the gut microbiome, form complex ecosystems capable of performing a diverse array of functions that have a wide spectrum of effects on their host's physiology and hence health ${ }^{1-3}$. Functions include those associated with digestion and nutrient status, but sensing of the gut microbiome is also understood to have profound effects on the immune system.

Much of this understanding is centred on the effects of the microbiome on the development of local immune responses in the gut, particularly those related to the crucial tasks of maintaining a healthy complex microbial composition and preventing microbes from breaching the simple (one-cell-thick/unilayered) epithelium $^{1,4,5}$ (Figure 1). For example, the production of immunoglobulin A ( $\operatorname{IgA}$ ) by gut plasma cells is important to ensure microbial diversity ${ }^{6-8}$, while interleukin-22 (IL-22) production by various lymphocyte subpopulations, including $\mathrm{T}$ helper type 17 (Th17) cells, $\gamma \delta \mathrm{T}$ cells, and type 3 innate lymphoid cells (ILC3s), stimulates antimicrobial protein release by epithelial cells ${ }^{9}$.

It is increasingly recognised that the gut microbiome can influence not only these local effects on the mucosal immune system but also cell-mediated systemic immune responses ${ }^{1,5,10}$ (Figure 1). Evidence suggests that such systemic effects of the microbiome are intrinsically linked to both early life development of appropriate local gut mucosal immune responses towards the microbiome and their subsequent maintenance across the life course. In this regard, early life exposure to antibiotics has been linked to the development of asthma ${ }^{11}$, while a decline of epithelial barrier function with age in mice leads to innate immune dysfunction in the bone marrow and peritoneum ${ }^{12}$. Moreover, ongoing gastrointestinal inflammation, as occurs in inflammatory bowel disease (IBD), is associated with immunemediated inflammation in distal organs, including the joints, skin, and eyes ${ }^{13,14}$. However, even in the healthy gut, microbial products constantly transit into the circulation ${ }^{15-17}$, and it has been suggested that in health the gastrointestinal microbiome acquires a rheostat-like function, tuning the systemic immune system $^{1}$.

In the 1980s and 1990s, studies using antibiotic treatment and germ-free (GF) mice highlighted effects of the microbiome on systemic immunity ${ }^{18,19}$, but owing to the recent dramatic advances in the microbiome field these systemic effects are now becoming an area of great research interest. In this commentary, we will focus on three actions that are emerging as key mechanisms by which the gut microbiome impacts systemic cell-mediated immunity and their implications for therapies. We will specifically discuss (1) lymphocyte polarisation, trafficking, and cross-reactivity; (2) direct effects of bacterial ligands on distal organ immune cell development and function; and (3) modulation of immune cell output during haematopoiesis.

\section{Lymphocyte polarisation, trafficking, and cross- reactivity}

At this time, perhaps the best-characterised mechanism by which the gut microbiome is known to influence systemic immune responses is via its influences on the adaptive immune system, particularly the T-cell compartment ${ }^{20,21}$. Indeed, in a number of animal models (described below), it has been established that modifying gut $\mathrm{T}$ cells can impact systemic disease either in a non-antigen-specific manner through bystander effects or in an antigen-specific fashion as a result of molecular mimicry by commensal factors.

In a mouse model of spontaneous autoimmune arthritis $(\mathrm{K} / \mathrm{BxN})$, GF or antibiotic-treated animals have lower serum autoantibody titres (that are associated with disease development) and ameliorated disease ${ }^{22}$. This is linked to decreased germinal centre formation systemically in the animals with depleted microbiota, hence explaining the lower serum autoantibodies. When the gut of GF animals was recolonised with Th17-inducing segmented filamentous bacteria (SFB), autoimmune arthritis incidence was restored. In this setting, activated Th17 cells from the gut trafficked to the spleen, where they supported germinal centre formation and ultimately increased production of diseasemediating autoantibodies ${ }^{22}$. Of note, this germinal centre formation is also dependent upon $\mathrm{T}$ follicular helper (Tfh) cells as in $\mathrm{K} / \mathrm{BxN}$ mice it has also been shown that $\mathrm{Tfh}$ cells generated in the Peyer's patches in response to SFB can transit to the spleen and support autoantibody production ${ }^{23}$.

Similarly, in experimental autoimmune encephalomyelitis (EAE), a murine model for multiple sclerosis, altering the gut microbiome has been shown to modulate central nervous system (CNS) autoimmunity in a T-cell-dependent manner. In a model of spontaneous EAE, SJL/J mice raised in GF conditions were protected against developing the disease while the introduction of commensal microbiota into the gut restored susceptibility ${ }^{24}$. Once again, when mice were mono-colonised with SFB, this induced Th17 cells in the gut and resulted in enhanced neurodegeneration in the $\mathrm{CNS}^{25}$.

The impact of the gut microbiome on peripheral T-cell subsets can also have positive effects on inflammatory diseases. Through its capacity to induce regulatory populations, the microbiome can also support the suppression of inflammatory responses. One particularly important mechanism is via the production of short-chain fatty acids (SCFAs), including butyrate, propionate, and acetate. SCFAs are generated by the microbiota as a result of its capacity to break down fibre and are now recognised as a keystone metabolite sensed by the immune system and capable of immunomodulation ${ }^{1,26}$. SCFAs promote the differentiation of peripherally induced regulatory $\mathrm{T}$ cells (Tregs) and in this 


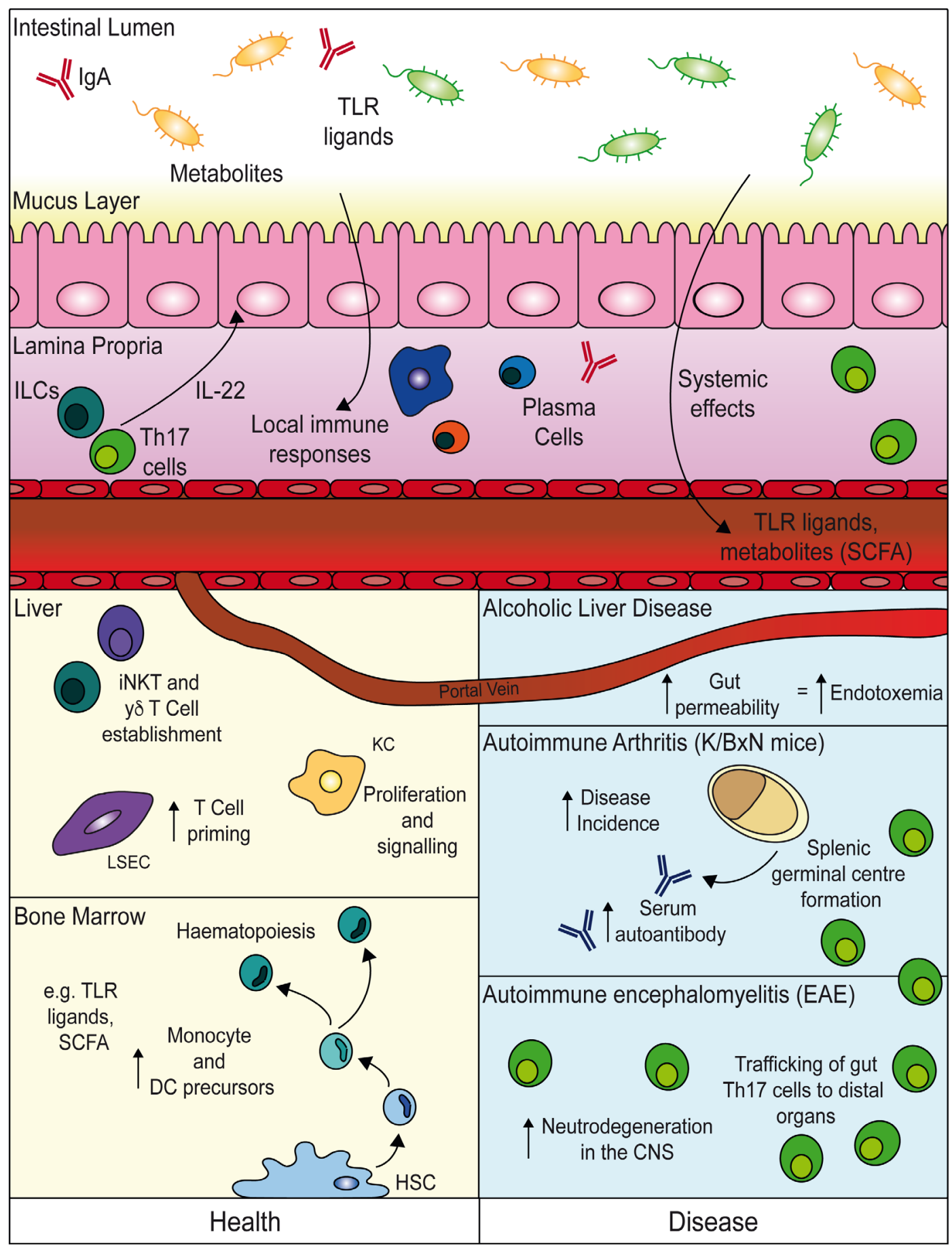

Figure 1. Effects of gut microbiota on systemic cell-mediated immune responses in health and disease. Much of the mucosal immune response towards the gut microbiota is focused on maintaining microbial diversity and supporting epithelial barrier function. Mechanisms include local production of immunoglobulin A (IgA) and production of the cytokine interleukin-22 (IL-22) to re-enforce epithelial barrier integrity. Even in the intact barrier, however, microbiota-derived ligands and metabolites enter into the circulatory system and impact immune populations at distal sites. These effects include tailoring of immune cell function in the liver and modulating bone marrow haematopoiesis. In disease states, the gastrointestinal barrier can become more leaky, leading to aberrant exposure to factors from the microbiome, as occurs in alcoholic liver disease. Additionally, in mouse models of T helper type 17 (Th17)-associated pathology (K/BxN arthritis and experimental autoimmune encephalomyelitis [EAE]), Th17 cells generated in response to commensal bacteria are thought to traffic from the gut and impact antibody generation and inflammation systemically. CNS, central nervous system; DC, dendritic cell; ILC, innate lymphoid cell; iNKT cell, invariant natural killer T cell; LSEC, liver sinusoidal endothelial cell; SCFA, short-chain fatty acid; TLR, Toll-like receptor. 
manner are capable of shifting the balance of effector $\mathrm{T}$ cells to Treg cells to limit the development of systemic inflammation ${ }^{27}$. Although butyrate and propionate are dominantly restricted to the gut and hepatic portal circulation ${ }^{26,28}$, acetate can be found in the circulation, implying that SCFAs could be directly sensed by circulating $\mathrm{T}$ cells to alter their function.

Antigen-specific T-cell responses, as opposed to the bystander effects already described, have also been shown to play both positive and negative roles in immune-mediated diseases. Of particular note, myelin basic protein (MBP)-specific $\mathrm{T}$ cells can respond to structurally related microbial peptides that can result in neurodegeneration ${ }^{29}$. Additionally, in autoimmune uveitis, $\mathrm{T}$ cells specific for self-antigens are first activated in the gut before trafficking to the ey $\mathrm{e}^{30}$. Conversely, myelin oligodendrocyte (MOG)-specific intraepithelial lymphocytes (IELs) were shown to transit from the gut to the CNS, where they were able to suppress neuroinflammation locally via a LAG3-dependent mechanism ${ }^{31}$, again demonstrating, as is the case for the bystander effect of the microbiome on $\mathrm{T}$ cells, that gut commensals can be important in balancing systemic immune responses.

\section{Distal organ immune cell development and function}

Independently of activation and T-cell trafficking from the gutassociated lymphoid tissue (GALT) to peripheral sites, resident immune cell function in organs distal to the gut can also be directly impacted by their sensing of circulating commensalderived factors. This is particularly well exemplified by the immune populations of the liver, an organ that receives about $80 \%$ of its blood via a major tributary associated with the gut, the portal vein $^{32-34}$. The composition of the immune compartment in the liver, as at other sites, is highly tailored to the specialised physiologic and immunologic requirements of the organ. Of note, the immune system of the liver, compared with that of other organs, is particularly enriched in unconventional lymphocyte populations, including invariant natural killer T (iNKT) cells and $\gamma \delta \mathrm{T}$ cells. These cells, which can respond to microbial lipids, are important in the protection against infections that manage to enter the circulation, but their aberrant activity can also lead to liver pathology $y^{33,35}$. A number of studies have implicated the gut microbiota in determining the establishment and function of these dominant cell populations.

iNKT cell numbers have been described to be positively or negatively regulated by the commensal microbiome depending on the strain of animal and type of microbiota present ${ }^{36}$. Additionally, iNKT cells can exhibit functional alterations in the absence of a commensal microbiome, as they have a lessmature phenotype and are hyporesponsive to stimulation with the lipid $\alpha$-galactosylceramide $(\alpha \text {-GalCer })^{37}$. A study by Li et al. showed that, alongside effects on iNKT cells, IL-17A-producing liver $\gamma \delta \mathrm{T}$ cells are also supported by the commensal microbiota ${ }^{35}$. Notably, GF or antibiotic-treated animals had reduced numbers of hepatic IL-17A-producing $\gamma \delta \mathrm{T}$ cells; complete restoration of this population was possible through recolonisation with a complex microbiota, whilst partial restoration occurred upon the addition of Escherichia coli alone in a dose-dependent manner ${ }^{35}$.
The liver is home to not only iNKT cells and $\gamma \delta \mathrm{T}$ cells but also various antigen-presenting cell populations, including dendritic cells (DCs) and the major liver-resident macrophage, the Kupffer cell $(\mathrm{KC})^{33,38}$. These cells are responsive to microbial signals via their expression of various Toll-like receptors (TLRs) ${ }^{39}$. In the early 1990s, it was suggested that KCs can recognise and respond to intestine-derived bacterial endotoxins ${ }^{40}$; more recently, it has been demonstrated that $\mathrm{KC}$ proliferation and major histocompatibility complex II (MHC II) expression are controlled by a live gut microbiome ${ }^{41}$. Indeed, aberrant changes to the gut microbiome are associated with increased hepatic inflammation, mediated partly by $\mathrm{KC}$ recognition of intestinal microbiota-associated molecular patterns via TLR-4/9 signalling and their subsequent upregulation of tumour necrosis factor-alpha $(\mathrm{TNF}-\alpha)^{42}$.

Though not a haematopoietic immune population, liver sinusoidal endothelial cells (LSECs) can also present antigens recognised in the sinusoidal space because of their expression of MHC I and MHC $\mathrm{II}^{43,44}$, various scavenger receptors ${ }^{45,46}$, and lymphocyte adhesion molecules such as DC-SIGN ${ }^{47}$. Along with $\mathrm{KCs}$, LSECs prime liver-localised $\mathrm{CD}^{+}$and $\mathrm{CD}^{+} \mathrm{T}$ cells in response to the recognition of microbe-associated ligands passing through the sinusoids that can originate from the intestine ${ }^{44}$. Thus, overall, the cellular composition and gross structure of the liver seem to co-operatively enable resident immunological subsets to respond to microbe-derived ligands derived from the intestinal microbiota.

As discussed, even in the absence of intestinal inflammation, the liver is chronically exposed to intestinally derived microbial products such as lipopolysaccharide (LPS). Owing to this baseline LPS exposure, endotoxin tolerance is observed in the liver and is associated with the priming and entrapment of tolerogenic $\mathrm{CD}^{+}$and $\mathrm{CD}^{+} \mathrm{T}$ cells by $\mathrm{LSECs}^{48,49}$ and IL-10 secretion by $\mathrm{KCs}$ and conventional $\mathrm{DCs}^{50,51}$. However, these immunologic subsets remain capable of responding to high LPS concentrations, and it is possible that increased LPS stimulation (greater than the baseline levels), or LPS exposure in conjunction with additional pathogen-associated molecular patterns (PAMPs)/ metabolites, acts as a means to signal alterations to the commensal microbiome or intestinal barrier breach or both. This was previously proposed by Belkaid and Naik, who suggested that the liver may sense a commensal microbiome 'molecular fingerprint' and that changes to this 'fingerprint' could act as an alarm to the periphery ${ }^{10}$. Perturbations to this dialogue between the gut and liver are exemplified by the pathological progression of alcoholic liver disease (ALD). ALD is associated with increased gut permeability (movement of commensal microbes outside of the gut) and in turn endotoxemia ${ }^{52}$, mediated by increased ethanol consumption and commensal outgrowth ${ }^{53}$, where the recognition of increased LPS titres by TLR-4 and CD14 leads to hepatic inflammation and steatosis ${ }^{54}$.

It is clear that immune populations in highly vascularised organs in addition to the liver can be impacted by the gut microbiome. In particular, non-mucosal mononuclear phagocytes have been shown to have altered methylation patterns at key genes 
associated with type I interferon (IFN) production in GF animals, leading to impaired priming of natural killer cells in the spleen $^{55}$. Whether this is mediated by direct effects of microbial ligands on mature immune populations or is due to alterations in haematopoietic development (as discussed in the next section) is unclear. As in the liver, these effects are just beginning to be explored and hold much potential for understanding systemic complications associated with shifts in the commensal microbiome.

\section{Modulation of immune cell output during haematopoiesis}

The ability of microbiome-derived ligands and their metabolites to enter the circulation allows resident bacteria in the gut to modulate the immune system from the earliest times of immune cell development during haematopoiesis ${ }^{56,57}$. Studies in the 1980s of GF animals, alongside specific pathogen-free animals treated with the antibiotic polymyxin, implicated Gramnegative commensal bacteria in promoting the development of bone marrow granulocyte-monocyte progenitor cells ${ }^{18}$. In line with this dependency of granulocyte-monocyte progenitors on the gut microbiota, more recent investigations established deficiencies in differentiated myeloid cell populations in both the spleen and the bone marrow of GF mice ${ }^{56}$.

Human and mouse haematopoietic stem cells express TLRs, providing a mechanism by which circulating microbiome-derived ligands could instruct haematopoiesis ${ }^{58-60}$. In humans, signalling via TLR-2 and TLR-7 directs haematopoietic differentiation towards a myeloid cell fate $\mathrm{f}^{61,62}$. After myeloid differentiation, microbiome-derived ligands can also augment the release of myeloid populations from the bone marrow. Sensing of low-level changes of the TLR-4 ligand LPS, which reflects fluctuations in circulating microbial molecules after their absorption from the gut, supports the release of mature monocytes from the murine bone marrow in a CCL-2-dependent fashion ${ }^{63}$.

Another mechanism by which the gut microbiome can influence haematopoiesis is via exposure to commensal-dependent metabolites. Systemic increases of the SCFA propionate, by administration in drinking water, led to alterations in bone marrow haematopoiesis characterised by enhanced DC precursor production $^{64}$. Gastrointestinal helminth infections can lead to alterations in the gut microbiota such that systemic SCFA levels are increased ${ }^{65}$. In line with these increases in SCFA during helminth infection, DC precursors are also modulated in the bone marrow ${ }^{65}$. Ultimately, this altered bone marrow output can have implications for inflammation at other mucosal sites. For example, following the administration of propionate in drinking water, the development of allergic responses in the lung is reduced. This alteration is associated with the presence of DCs that have impaired T-cell-activating capacity in the lung ${ }^{64}$. This finding highlights the possibility that manipulating the factors, such as metabolites, that gut microbiota produce limits inflammation at distal sites.

\section{Therapeutic opportunities and future directions}

As highlighted, better characterisation of the gut microbiota and understanding of its mechanisms of action on systemic immune responses hold tremendous opportunities for the development of therapeutics and also patient stratification. Two current areas of particular research interest are cancer therapy and vaccination responses ${ }^{66,67}$.

GF and antibiotic-treated mice show reduced tumour regression and impaired survival following treatment with chemotherapeutic agents compared with controls ${ }^{68,69}$, while recolonisation with specific bacterial species can lead to a restored anti-tumour efficacy ${ }^{70}$. Recently, immunotherapy has revolutionised cancer treatment, particularly with regard to checkpoint blockade. In this context, T-cell pathways that are associated with regulatory checkpoints, such as PD-1 and CTLA-4, are inhibited to augment anti-tumour responses ${ }^{71}$. Remarkably, the capacity of CTLA-4 blockade to have anti-tumour effects was reliant on Bacteroides species ${ }^{72}$. Both a mouse model and studies in patients revealed that specific T-cell responses to Bacteroides thetaiotaomicron and Bacteroides fragilis correlate with the efficacy of CTLA-4 blockade ${ }^{72}$. In a similar vein, Bifidobacterium was shown to improve melanoma control alongside PD-L1specific antibody therapy. Indeed, in tandem, the presence of Bifidobacterium with PD-L1 resulted in tumour clearance ${ }^{73}$.

It is becoming clear that the precise gut microbiome of an individual also has implications for the development of vaccinemediated protection. This has perhaps been best demonstrated in GF animals or animals treated with antibiotics, where an absence or reduced gut microbiome is associated with impaired IgG and $\operatorname{IgM}$ responses to the seasonal influenza vaccine ${ }^{74}$. This effect is dependent upon the capacity of the microbiome to act as an adjuvant via TLR-5-mediated sensing of bacterial flagellin. Oral reconstitution of GF mice with flagellated strains of $E$. coli (but not aflagellated forms) restored vaccine responses. Interestingly, this effect may be specific to certain types of vaccine, as the seasonal influenza vaccine is a non-adjuvanted vaccine ${ }^{74}$. Studies of human cohorts, alongside murine models, have demonstrated effects of the microbiome on vaccine responses. For example, the relative abundance of specific bacterial species in stool microbiota of a small cohort of Bangladeshi infants was correlated with vaccine-specific $\operatorname{IgG}$ and $\mathrm{T}$-cell proliferation towards vaccinations, including Bacillus Calmette-Guérin and hepatitis $\mathrm{B}$ vaccine ${ }^{75}$.

Researchers are just beginning to understand the variety of mechanisms by which the gut microbiome can influence systemic immunity and the implications of this for human health. This review has highlighted three distinct types of mechanism that are already being explored (Figure 1). Another emerging field, not discussed here, that is likely to be critical to the modulation of systemic immunity by the gut microbiota consists of interactions with the nervous system. It is well established that the microbiome is involved in instructing the nervous system, but precisely how this can lead to alterations in the peripheral immune system is less well understood ${ }^{76}$. It is clear that, irrespective of the exact mechanisms, improved understanding of the key pathways and bacterial species involved in systemic instruction of the immune system holds promise to inform the development of novel therapeutic strategies to modify immune function. One such evolving strategy is faecal microbiota transplantation (FMT), in 
which the faecal material from a healthy donor is transferred to a patient with suspected microbial dysbiosis to restore diversity of the commensal microbiota ${ }^{77}$. FMT has been used successfully to treat recurrent Clostridium difficile infection in patients without $\mathrm{IBD}^{77,78}$, and studies suggest that FMT may be beneficial to some patients with $\mathrm{IBD}^{79}$. Whether FMT can also promote the resolution of systemic disease symptoms associated with gut inflammation and microbial alterations is just beginning to be explored, and studies are underway in diseases, including psoriatic arthritis ${ }^{80}$.

Another widely promoted approach for modulating the gut microbiome is the use of probiotic therapies ${ }^{81,82}$. In rodent models, probiotics can improve systemic inflammatory disease, such as joint inflammation ${ }^{83}$. However, a recent publication has suggested that, following antibiotic treatment, the use of probiotics may compromise gut mucosal recovery, demonstrating that such therapies need to be employed with caution ${ }^{84}$. These early studies of microbiome-modifying therapies reveal that much future work is required to translate our rapidly advancing knowledge of how the gut microbiome impacts systemic immunity into altered patient outcomes. Even so, there is no doubt that such research does hold much promise for improving treatments in diverse disease states from cancer to autoimmunity.

\section{Grant information}

John R. Grainger is the recipient of a Senior Fellowship funded by the Kennedy Trust for Rheumatology Research. Rufus H. Daw is supported by the Medical Research Council (MRC) Doctoral Training Programme at The University of Manchester. Kelly Wemyss is supported by the Engineering and Physical Sciences Research Council and MRC Centre for Doctoral Training in Regenerative Medicine at The University of Manchester (EP/L014904/1). This work was also supported in part by The Wellcome Trust (grant 104195/Z/14/Z).

The funders had no role in study design, data collection and analysis, decision to publish, or preparation of the manuscript.
1. Belkaid Y, Harrison OJ: Homeostatic Immunity and the Microbiota. Immunity. 2017; 46(4): 562-76.

PubMed Abstract | Publisher Full Text | Free Full Text

2. Levy M, Blacher E, Elinav E: Microbiome, metabolites and host immunity. Curr Opin Microbiol. 2017; 35: 8-15.

PubMed Abstract | Publisher Full Text

3. Gilbert JA, Blaser MJ, Caporaso JG, et al.: Current understanding of the human microbiome. Nat Med. 2018; 24(4): 392-400.

PubMed Abstract | Publisher Full Text

4. Allaire JM, Crowley SM, Law HT, et al:: The Intestinal Epithelium: Central Coordinator of Mucosal Immunity. Trends Immunol. 2018; 39(9): 677-96. PubMed Abstract | Publisher Full Text

5. Blander JM, Longman RS, lliev ID, et al:: Regulation of inflammation by microbiota interactions with the host. Nat Immunol. 2017; 18(8): 851-60. PubMed Abstract | Publisher Full Text | Free Full Text

6. Pabst O, Cerovic V, Hornef M: Secretory IgA in the Coordination of Establishment and Maintenance of the Microbiota. Trends Immunol. 2016; 37(5): 287-96.

PubMed Abstract | Publisher Full Text

7. Reikvam DH, Derrien M, Islam R, et al.: Epithelial-microbial crosstalk in polymeric Ig receptor deficient mice. Eur J Immunol. 2012; 42(11): 2959-70. PubMed Abstract | Publisher Full Text

8. F Wei M, Shinkura R, Doi Y, et al:: Mice carrying a knock-in mutation of Aicda resulting in a defect in somatic hypermutation have impaired gut homeostasis and compromised mucosal defense. Nat Immunol. 2011; 12(3): 264-70. PubMed Abstract | Publisher Full Text | F1000 Recommendation

9. Sonnenberg GF, Fouser LA, Artis D: Border patrol: regulation of immunity, inflammation and tissue homeostasis at barrier surfaces by IL-22. Nat Immunol. 2011; 12(5): 383-90. PubMed Abstract | Publisher Full Text

10. Belkaid $\mathrm{Y}$, Naik S: Compartmentalized and systemic control of tissue immunity by commensals. Nat Immunol. 2013; 14(7): 646-53. PubMed Abstract | Publisher Full Text | Free Full Text

11. Wypych TP, Marsland BJ: Antibiotics as Instigators of Microbial Dysbiosis: Implications for Asthma and Allergy. Trends Immunol. 2018; 39(9): 697-711. PubMed Abstract | Publisher Full Text

12. F Thevaranjan N, Puchta A, Schulz C, et al:: Age-Associated Microbial Dysbiosis Promotes Intestinal Permeability, Systemic Inflammation, and Macrophage Dysfunction. Cell Host Microbe. 2017; 21(4): 455-466.e4. PubMed Abstract | Publisher Full Text | Free Full Text | F1000 Recommendation

13. Levine JS, Burakoff R: Extraintestinal manifestations of inflammatory bowel disease. Gastroenterol Hepatol (N Y). 2011; 7(4): 235-41.

PubMed Abstract | Free Full Text
14. Bernstein CN, Blanchard JF, Rawsthorne $\mathrm{P}$, et al:: The prevalence of extraintestinal diseases in inflammatory bowel disease: a population-based study. Am J Gastroenterol. 2001; 96(4): 1116-22. PubMed Abstract | Publisher Full Text

15. F Uchimura Y, Fuhrer T, Li H, et al.: Antibodies Set Boundaries Limiting Microbial Metabolite Penetration and the Resultant Mammalian Host Response. Immunity. 2018; 49(3): 545-559.e5.

PubMed Abstract | Publisher Full Text | Free Full Text | F1000 Recommendation

16. Balmer ML, Schürch $\mathrm{CM}$, Saito $\mathrm{Y}$, et al:: Microbiota-derived compounds drive steady-state granulopoiesis via MyD88/TICAM signaling. J Immunol. 2014; 193(10): 5273-83.

PubMed Abstract | Publisher Full Text

17. $\mathrm{F}$ Hergott $\mathrm{CB}$, Roche AM, Tamashiro $\mathrm{E}$, et al.: Peptidoglycan from the gut microbiota governs the lifespan of circulating phagocytes at homeostasis. Blood. 2016; 127(20): 2460-71.

PubMed Abstract | Publisher Full Text | Free Full Text | F1000 Recommendation

18. Goris $\mathrm{H}$, de Boer F, van der Waaij $\mathrm{D}$ : Myelopoiesis in experimentally contaminated specific-pathogen-free and germfree mice during oral administration of polymyxin. Infect Immun. 1985; 50(2): 437-41. PubMed Abstract | Free Full Text

19. Tada T, Yamamura S, Kuwano Y, et al.: Level of myelopoiesis in the bone marrow is influenced by intestinal flora. Cell Immunol. 1996; 173(1): 155-61. PubMed Abstract | Publisher Full Text

20. Honda K, Littman DR: The microbiota in adaptive immune homeostasis and disease. Nature. 2016; 535(7610): 75-84.

PubMed Abstract | Publisher Full Text

21. Longman RS, Littman DR: The functional impact of the intestinal microbiome on mucosal immunity and systemic autoimmunity. Curr Opin Rheumatol. 2015 27(4): 381-7.

PubMed Abstract | Publisher Full Text | Free Full Text

22. F Wu HJ, Ivanov II, Darce J, et al.: Gut-residing segmented filamentous bacteria drive autoimmune arthritis via T helper 17 cells. Immunity. 2010; 32(6): 815-27.

PubMed Abstract | Publisher Full Text | Free Full Text | F1000 Recommendation

23. $\mathrm{F}$ Teng $\mathrm{F}$, Klinger CN, Felix KM, et al:: Gut Microbiota Drive Autoimmune Arthritis by Promoting Differentiation and Migration of Peyer's Patch T Follicular Helper Cells. Immunity. 2016; 44(4): 875-88.

PubMed Abstract | Publisher Full Text | Free Full Text | F1000 Recommendation

24. $\mathrm{F}$ Berer $\mathrm{K}$, Mues M, Koutrolos $\mathrm{M}$, et al:: Commensal microbiota and myelin autoantigen cooperate to trigger autoimmune demyelination. Nature. 2011; 479(7374): 538-41.

PubMed Abstract | Publisher Full Text | F1000 Recommendation

25. F Lee YK, Menezes JS, Umesaki Y, et al:: Proinflammatory T-cell responses 
to gut microbiota promote experimental autoimmune encephalomyelitis. Proc Natl Acad Sci U S A. 2011; 108 Suppl 1: 4615-22.

PubMed Abstract | Publisher Full Text | Free Full Text | F1000 Recommendation

26. Sun M, Wu W, Liu Z, et al:: Microbiota metabolite short chain fatty acids, GPCR, and inflammatory bowel diseases. J Gastroenterol. 2017; 52(1): 1-8. PubMed Abstract | Publisher Full Text | Free Full Text

27. Arpaia N, Campbell C, Fan X, et al:: Metabolites produced by commensa bacteria promote peripheral regulatory T-cell generation. Nature. 2013; 504(7480): 451-5.

PubMed Abstract | Publisher Full Text | Free Full Text

28. Bloemen JG, Venema K, van de Poll MC, et al: Short chain fatty acids exchang across the gut and liver in humans measured at surgery. Clin Nutr. 2009; 28(6): 657-61.

PubMed Abstract | Publisher Full Tex

29. F Harkiolaki M, Holmes SL, Svendsen P, et al.: T cell-mediated autoimmune disease due to low-affinity crossreactivity to common microbial peptides. Immunity. 2009; 30(3): 348-57.

PubMed Abstract | Publisher Full Text | F1000 Recommendation

30. F Horai R, Zárate-Bladés CR, Dillenburg-Pilla $P$, et al:: Microbiota-Dependen Activation of an Autoreactive T Cell Receptor Provokes Autoimmunity in an Immunologically Privileged Site. Immunity. 2015; 43(2): 343-53. PubMed Abstract | Publisher Full Text | Free Full Text | F1000 Recommendation

31. F Kadowaki A, Miyake S, Saga R, et al:: Gut environment-induced intraepithelial autoreactive $\mathrm{CD} 4^{+} \mathrm{T}$ cells suppress central nervous system autoimmunity via LAG-3. Nat Commun. 2016; 7: 11639. PubMed Abstract | Publisher Full Text | Free Full Text | F1000 Recommendation

32. Crispe IN: The liver as a lymphoid organ. Annu Rev Immunol. 2009; 27: 147-63. PubMed Abstract | Publisher Full Text

33. F Macpherson AJ, Heikenwalder M, Ganal-Vonarburg SC: The Liver at the Nexus of Host-Microbial Interactions. Cell Host Microbe. 2016; 20(5): 561-71. PubMed Abstract | Publisher Full Text |F1000 Recommendation

34. Adolph TE, Grander C, Moschen AR, et al:: Liver-Microbiome Axis in Health and Disease. Trends Immunol. 2018; 39(9): 712-23. PubMed Abstract | Publisher Full Text

35. F Li F, Hao X, Chen Y, et al:: The microbiota maintain homeostasis of liverresident $\gamma \delta$ T-17 cells in a lipid antigen/CD1d-dependent manner. Nat Commun. 2017; 7: 13839 .

PubMed Abstract | Publisher Full Text | Free Full Text | F1000 Recommendation

36. F Olszak T, An D, Zeissig S, et al:: Microbial exposure during early life has persistent effects on natural killer T cell function. Science. 2012; 336(6080): 489-93.

PubMed Abstract | Publisher Full Text | Free Full Text | F1000 Recommendation

37. Wingender $G$, Stepniak D, Krebs $P$, et al:: Intestinal microbes affect phenotypes and functions of invariant natural killer T cells in mice. Gastroenterology. 2012; 143(2): 418-28.

PubMed Abstract | Publisher Full Text | Free Full Text

38. F Gomez Perdiguero E, Klapproth K, Schulz C, et al:: Tissue-resident macrophages originate from yolk-sac-derived erythro-myeloid progenitors. Nature. 2015; 518(7540): 547-51.

PubMed Abstract | Publisher Full Text | Free Full Text | F1000 Recommendation

39. Mencin A, Kluwe J, Schwabe RF: Toll-like receptors as targets in chronic liver diseases. Gut. 2009; 58(5): 704-20.

PubMed Abstract | Publisher Full Text | Free Full Text

40. Nolan JP: Intestinal endotoxins as mediators of hepatic injury--an idea whose time has come again. Hepatology. 1989; 10(5): 887-91.

PubMed Abstract | Publisher Full Text

41. Corbitt N, Kimura S, Isse K, et al:: Gut bacteria drive Kupffer cell expansion via MAMP-mediated ICAM-1 induction on sinusoidal endothelium and influence preservation-reperfusion injury after orthotopic liver transplantation. $A m \mathrm{~J}$ Pathol. 2013; 182(1): 180-91.

PubMed Abstract | Publisher Full Text | Free Full Text

42. F Henao-Mejia J, Elinav E, Jin C, et al.: Inflammasome-mediated dysbiosis regulates progression of NAFLD and obesity. Nature. 2012; 482(7384): 179-85. PubMed Abstract | Publisher Full Text | Free Full Text | F1000 Recommendation

43. Schölzel K, Schildberg FA, Welz M, et al:: Transfer of MHC-class-I molecules among liver sinusoidal cells facilitates hepatic immune surveillance. $J$ Hepatol. 2014; 61(3): 600-8.

PubMed Abstract | Publisher Full Text

44. F Wittlich M, Dudek M, Böttcher JP, et al:: Liver sinusoidal endothelial cell cross-priming is supported by CD4 T cell-derived IL-2. J Hepatol. 2017; 66(5): 978-86.

PubMed Abstract | Publisher Full Text | F1000 Recommendation

45. Elvevold K, Simon-Santamaria J, Hasvold H, et al.: Liver sinusoidal endothelial cells depend on mannose receptor-mediated recruitment of lysosomal enzymes for normal degradation capacity. Hepatology. 2008; 48(6): 2007-15. PubMed Abstract | Publisher Full Text

46. F Ganesan LP, Mates JM, Cheplowitz AM, et al.: Scavenger receptor B1, the HDL receptor, is expressed abundantly in liver sinusoidal endothelial cells. $S c i$ Rep. 2016; 6: 20646

PubMed Abstract | Publisher Full Text | Free Full Text | F1000 Recommendation

47. Bashirova AA, Geijtenbeek TB, van Duijnhoven GC et al: A dendritic cell-specific intercellular adhesion molecule 3-grabbing nonintegrin (DC-SIGN)-related protein is highly expressed on human liver sinusoidal endothelial cells and promotes HIV-1 infection. J Exp Med. 2001; 193(6): 671-8.

PubMed Abstract | Publisher Full Text | Free Full Text

48. Limmer $\mathrm{A}, \mathrm{Ohl} \mathrm{J}$, Kurts $\mathrm{C}$, et al:: Efficient presentation of exogenous antigen by liver endothelial cells to $C D 8^{+} \mathrm{T}$ cells results in antigen-specific T-cell tolerance. Nat Med. 2000; 6(12): 1348-54.

PubMed Abstract | Publisher Full Text

49. John B, Crispe IN: TLR-4 regulates $\mathrm{CD}^{+} \mathbf{T}$ cell trapping in the liver. $\mathrm{J}$ Immunol. 2005; 175(3): 1643-50.

PubMed Abstract | Publisher Full Text

50. Bamboat ZM, Ocuin LM, Balachandran VP, et al:: Conventional DCs reduce live ischemia/reperfusion injury in mice via IL-10 secretion. J Clin Invest. 2010; 120(2): 559-69.

PubMed Abstract | Publisher Full Text | Free Full Text

51. Knolle P, Schlaak J, Uhrig A, et al.: Human Kupffer cells secrete IL-10 in response to lipopolysaccharide (LPS) challenge. J Hepatol. 1995; 22(2): 226-9. PubMed Abstract | Publisher Full Text

52. Elamin EE, Masclee AA, Dekker J, et al.: Ethanol metabolism and its effects on the intestinal epithelial barrier. Nutr Rev. 2013; 71(7): 483-99. PubMed Abstract | Publisher Full Text

53. Yan AW, Fouts DE, Brandl J, et al.: Enteric dysbiosis associated with a mouse model of alcoholic liver disease. Hepatology. 2011; 53(1): 96-105. PubMed Abstract | Publisher Full Text | Free Full Text

54. Uesugi T, Froh M, Arteel GE, et al.: Toll-like receptor 4 is involved in the mechanism of early alcohol-induced liver injury in mice. Hepatology. 2001; 34(1): 101-8.

PubMed Abstract | Publisher Full Text

55. Ganal SC, Sanos SL, Kallfass C, et al.: Priming of natural killer cells by nonmucosal mononuclear phagocytes requires instructive signals from commensal microbiota. Immunity. 2012; 37(1): 171-86. PubMed Abstract | Publisher Full Text

56. F Khosravi A, Yáñez A, Price JG, et al.: Gut microbiota promote hematopoiesis to control bacterial infection. Cell Host Microbe. 2014; 15(3): 374-81.

PubMed Abstract | Publisher Full Text | Free Full Text | F1000 Recommendation

57. F Josefsdottir KS, Baldridge MT, Kadmon CS, et al:: Antibiotics impair murine hematopoiesis by depleting the intestinal microbiota. Blood. 2017; 129(6): 729-39.

PubMed Abstract | Publisher Full Text | Free Full Text | F1000 Recommendation

58. $\mathrm{F}$ Nagai $\mathrm{Y}$, Garrett KP, Ohta S, et al:: Toll-like receptors on hematopoietic progenitor cells stimulate innate immune system replenishment. Immunity. 2006; 24(6): 801-12.

PubMed Abstract | Publisher Full Text | Free Full Text | F1000 Recommendation

59. F Massberg S, Schaerli P, Knezevic-Maramica I, et al:: Immunosurveillance by hematopoietic progenitor cells trafficking through blood, lymph, and peripheral tissues. Cell. 2007; 131(5): 994-1008.

PubMed Abstract | Publisher Full Text | Free Full Text | F1000 Recommendation

60. Sioud M, Fløisand $Y$, Forfang L, et al.: Signaling through toll-like receptor $7 / 8$ induces the differentiation of human bone marrow CD34+ progenitor cells along the myeloid lineage. J Mol Biol. 2006; 364(5): 945-54.

PubMed Abstract | Publisher Full Text

61. De Luca K, Frances-Duvert V, Asensio MJ, et al.: The TLR1/2 agonist PAM ${ }_{3}$ CSK instructs commitment of human hematopoietic stem cells to a myeloid cell fate. Leukemia. 2009; 23(11): 2063-74. PubMed Abstract | Publisher Full Text

62. Sioud M, Fløisand Y: TLR agonists induce the differentiation of human bone marrow $\mathrm{CD} 34^{+}$progenitors into $\mathrm{CD} 11 \mathrm{c}^{+} \mathrm{CD} 80 / 86^{+} \mathrm{DC}$ capable of inducing a Th1-type response. Eur J Immunol. 2007; 37(10): 2834-46. PubMed Abstract | Publisher Full Text

63. F Shi C, Jia T, Mendez-Ferrer S, et al.: Bone marrow mesenchymal stem and progenitor cells induce monocyte emigration in response to circulating tolllike receptor ligands. Immunity. 2011; 34(4): 590-601. PubMed Abstract | Publisher Full Text | Free Full Text | F1000 Recommendation

64. F Trompette A, Gollwitzer ES, Yadava K, et al.: Gut microbiota metabolism of dietary fiber influences allergic airway disease and hematopoiesis. Nat Med. 2014; 20(2): 159-66.

PubMed Abstract | Publisher Full Text | F1000 Recommendation

65. F Zaiss MM, Rapin A, Lebon L, et al.: The Intestinal Microbiota Contributes to the Ability of Helminths to Modulate Allergic Inflammation. Immunity. 2015 43(5): 998-1010.

PubMed Abstract | Publisher Full Text | Free Full Text | F1000 Recommendation

66. F Lynn DJ, Pulendran B: The potential of the microbiota to influence vaccine responses. J Leukoc Biol. 2018; 103(2): 225-31.

PubMed Abstract | Publisher Full Text | Free Full Text | F1000 Recommendation

67. F Roy S, Trinchieri G: Microbiota: a key orchestrator of cancer therapy. Nat Rev Cancer. 2017; 17(5): 271-85. PubMed Abstract | Publisher Full Text | F1000 Recommendation

68. F lida N, Dzutsev A, Stewart CA, et al:: Commensal bacteria control cance response to therapy by modulating the tumor microenvironment. Science. 2013; 342(6161): 967-70.

PubMed Abstract | Publisher Full Text | F1000 Recommendation

69. F Viaud S, Saccheri F, Mignot G, et al.: The intestinal microbiota modulates 
the anticancer immune effects of cyclophosphamide. Science. 2013; 342(6161): 971-6.

PubMed Abstract | Publisher Full Text | Free Full Text | F1000 Recommendation

70

F Daillère R, Vétizou M, Waldschmitt N, et al.: Enterococcus hirae and Barnesiella intestinihominis Facilitate Cyclophosphamide-Induced Therapeutic Immunomodulatory Effects. Immunity. 2016; 45(4): 931-43.

PubMed Abstract | Publisher Full Text | F1000 Recommendation

71. Zappasodi R, Merghoub T, Wolchok JD: Emerging Concepts for Immune Checkpoint Blockade-Based Combination Therapies. Cancer Cell. 2018; 33(4): 581-98.

PubMed Abstract | Publisher Full Text | Free Full Text

72. F Vétizou M, Pitt JM, Daillère R, et al:: Anticancer immunotherapy by CTLA-4 blockade relies on the gut microbiota. Science. 2015; 350(6264): 1079-84. PubMed Abstract | Publisher Full Text | Free Full Text | F1000 Recommendation

73. F Sivan A, Corrales L, Hubert N, et al:: Commensal Bifidobacterium promotes antitumor immunity and facilitates anti-PD-L1 efficacy. Science. 2015; 350(6264): 1084-9.

PubMed Abstract | Publisher Full Text | Free Full Text | F1000 Recommendation

74. F Oh JZ, Ravindran R, Chassaing B, et al:: TLR5-mediated sensing of gut microbiota is necessary for antibody responses to seasonal influenza vaccination. Immunity. 2014; 41(3): 478-92.

PubMed Abstract | Publisher Full Text | Free Full Text | F1000 Recommendation

75. Huda MN, Lewis Z, Kalanetra KM, et al.: Stool microbiota and vaccine responses of infants. Pediatrics. 2014; 134(2): e362-72. PubMed Abstract | Publisher Full Text | Free Full Text

76. F Sharon G, Sampson TR, Geschwind DH, et al:: The Central Nervous System and the Gut Microbiome. Cell. 2016; 167(4): 915-32.

PubMed Abstract | Publisher Full Text | Free Full Text | F1000 Recommendation

77. F Gianotti RJ, Moss AC: Fecal Microbiota Transplantation: From Clostridium difficile to Inflammatory Bowel Disease. Gastroenterol Hepatol (N Y). 2017; 13(4): $209-13$.

PubMed Abstract | Free Full Text | F1000 Recommendation

78. F Kelly CR, Khoruts A, Staley C, et al:: Effect of Fecal Microbiota Transplantation on Recurrence in Multiply Recurrent Clostridium difficile Infection: A Randomized Trial. Ann Intern Med. 2016; 165(9): 609-16.

PubMed Abstract | Publisher Full Text | Free Full Text | F1000 Recommendation

79. Kelly CR, Ihunnah C, Fischer M, et al.: Fecal microbiota transplant for treatment of Clostridium difficile infection in immunocompromised patients. $\mathrm{Am} \mathrm{J}$ Gastroenterol. 2014; 109(7): 1065-71.

PubMed Abstract | Publisher Full Text | Free Full Text

80. Kragsnaes MS, Kjeldsen J, Horn HC, et al.: Efficacy and safety of faecal microbiota transplantation in patients with psoriatic arthritis: protocol for a 6-month, double-blind, randomised, placebo-controlled trial. BMJ Open. 2018 8(4): e019231.

PubMed Abstract | Publisher Full Text | Free Full Text

81. Vitetta L, Coulson S, Linnane AW, et al.: The gastrointestinal microbiome and musculoskeletal diseases: a beneficial role for probiotics and prebiotics. Pathogens. 2013; 2(4): 606-26.

PubMed Abstract | Publisher Full Text | Free Full Text

82. Reid G, Jass J, Sebulsky MT, et al:: Potential uses of probiotics in clinical practice. Clin Microbiol Rev. 2003; 16(4): 658-72.

PubMed Abstract | Publisher Full Text | Free Full Text

83. So JS, Kwon HK, Lee CG, et al.: Lactobacillus casei suppresses experimental arthritis by down-regulating T helper 1 effector functions. Mol Immunol. 2008; 45(9): 2690-9.

PubMed Abstract | Publisher Full Text

84. F Suez J, Zmora N, Zilberman-Schapira G, et al:: Post-Antibiotic Gut Mucosal Microbiome Reconstitution Is Impaired by Probiotics and Improved by Autologous FMT. Cell. 2018; 174(6): 1406-1423.e16.

PubMed Abstract | Publisher Full Text | F1000 Recommendation 


\section{Open Peer Review}

\section{Current Peer Review Status:}

\section{Editorial Note on the Review Process}

Faculty Reviews are review articles written by the prestigious Members of Faculty Opinions. The articles are commissioned and peer reviewed before publication to ensure that the final, published version is comprehensive and accessible. The reviewers who approved the final version are listed with their names and affiliations.

\section{The reviewers who approved this article are:}

\section{Version 1}

\section{Jonathan Braun}

Department of Pathology and Laboratory Medicine, University of California, Los Angeles, Los Angeles, California, USA

Competing Interests: No competing interests were disclosed.

\section{Luis Vitetta}

Sydney Medical School, University of Sydney, Sydney, NSW, Australia

Competing Interests: No competing interests were disclosed.

The benefits of publishing with F1000Research:

- Your article is published within days, with no editorial bias

- You can publish traditional articles, null/negative results, case reports, data notes and more

- The peer review process is transparent and collaborative

- Your article is indexed in PubMed after passing peer review

- Dedicated customer support at every stage

For pre-submission enquiries, contact research@f1000.com 